\title{
Arab and Latin American Literature: Mourid Barghouti, Najla Said, and Lina Meruane in Palestine
}

\section{Tahia Abdel Nasser}

\section{CpenEdition}

\section{Journals}

Electronic version

URL: https://journals.openedition.org/ces/4626

DOI: $10.4000 /$ ces.4626

ISSN: 2534-6695

\section{Publisher}

SEPC (Société d'études des pays du Commonwealth)

\section{Printed version}

Date of publication: 1 April 2017

Number of pages: 63-75

ISSN: 2270-0633

\section{Electronic reference}

Tahia Abdel Nasser, "Arab and Latin American Literature: Mourid Barghouti, Najla Said, and Lina Meruane in Palestine", Commonwealth Essays and Studies [Online], 39.2 | 2017, Online since 03 April 2021, connection on 04 June 2021. URL: http://journals.openedition.org/ces/4626 ; DOI: https:// doi.org/10.4000/ces.4626

\section{(c) $(1) \&$}

Commonwealth Essays and Studies is licensed under a Licence Creative Commons Attribution - Pas d'Utilisation Commerciale - Pas de Modification 4.0 International. 


\section{Arab and Latin American Literature: Mourid Barghouti, Najla Said, and Lina Meruane in Palestine}

Over the past quarter-century, the production of memoirs on Palestine in Arabic, English, and, more recently, Spanish animated the genre. This article compares diasporic memoirs of return to Palestine: Palestinian poet Mourid Barghouti's Ra'aytu Ramallah (1996), Arab-American author Najla Said's Looking for Palestine: Growing Up Confused in an ArabAmerican Family (2013), and Chilean writer Lina Meruane's Volverse Palestina (2013). Examining the narrative of return genre across three languages illuminates how Arab, Arab-American, and Latin American writers of Arab ancestry contribute to the rise of new memoirs in Arabic, English, and Spanish within a global cultural production on Palestine.

For more than a quarter-century, the production of memoirs on Palestine in Arabic, English, and, more recently, Spanish animated the genre. In the twenty-first century, diasporic narratives of return have formed part global cultural production on Palestine. Mahmoud Darwish, Mourid Barghouti, and Annemarie Jacir have elaborated narratives of return rooted in experiences of dispossession, exile, and diaspora. While Arab and Arab-American writers have penned memoirs that revisit the dispossession or focus on the diaspora, Latin American writers of Palestinian ancestry have begun to contribute to a global cultural production. These narratives of return have crisscrossed the world, tracing routes of comparison across the Arab world, between Europe and the Middle East, North America and the Middle East, and Latin America and Palestine.

Francophone and Anglophone Arab autobiography has opened up ways for literature to migrate between languages and in turn to be enriched by this migration. For much of the twentieth century, exile, migration, exchange, and translation recreated Arab autobiographical production. Darwish, for example, moved between the Arab world, Moscow, and Paris and Barghouti moved between Palestine, Egypt, and Hungary. In Arabic and Anglophone Palestinian memoirs, language has played a central role in the narrativization of experiences of dispossession and return and, for writers who came into contact with other languages, these narratives are infused with further histories, trajectories, and interactions. The languages of memoirs are intimately intertwined with the writers' location and historical context. For example, memoirs in Arabic draw on Palestinian experience and a rich history of Arab cultural production, while memoirs in English explore a history of dispossession along with an Arab-American background. More recently, Spanish has offered another language through which writers explore Palestinian ancestry and images of Palestine in Latin America.

This article compares diasporic memoirs of return to Palestine: Palestinian poet Mourid Barghouti's Ra'aytu Ramallah (I Saw Ramallah, 1996), Arab-American author Najla Said's Looking for Palestine: Growing Up Confused in an Arab-American Family (2013), and Chilean writer Lina Meruane's Volverse Palestina (Becoming Palestine, 2013). Barghouti's Ra'aytu Ramallah recounts his twelve-day visit to his ancestral village of Deir Ghassaneh in 1996 after a thirty-year exile. Said's Looking for Palestine explores her Arab-American youth in the United States and her belated discovery of Palestine. Remarkably for Chilean writers of Palestinian ancestry, Meruane's Volverse Palestina chronicles her re- 
turn to Palestine in 2012 in search of the origins of her family name. These memoirs, written in Arabic, English, and Spanish, trace trajectories, continuities, and networks that contribute to the comparative study of Arab literature. Examining the narrative of return genre across three languages illuminates how Arab, Arab-American, and Latin American writers of Arab ancestry elaborate the return to Palestine and contribute to the rise of new memoirs in Arabic, English, and Spanish within a growing global corpus. These writers have produced new memoirs that explore ties to Palestine within such contexts as post-9/11 America and hitherto unexplored connections between $\mathrm{Pa}$ lestine and Latin America. Barghouti's memoirs have been the subject of some critical attention (Bernard; Abdel Nasser; Mattar). In contrast, Said and Meruane's memoirs are little known and have never been the subject of a critical study. Both memoirs examine young Arab-American and Chilean-Palestinian women's search for Palestine and Palestinian roots in similar ways within a genre represented by Barghouti's famous memoir, though the narrative of return is framed in different contexts, languages, backgrounds, and ties to Palestine.

This comparative framework allows us to assess the effect of language and relocation on diasporic memoirs. In Ra'aytu Ramallah, Looking for Palestine, and Volverse Palestina, I argue, language and location contribute to images of Palestine and Palestinianness: the legacy of Palestinian dispossession in the Arab world, the articulation of Palestinianness in the United States, and Palestinian resonances in Chile. These narratives of return offer polylingual reworkings of the form and transnational networks within a rich canon of Palestinian cultural production.

\section{Arabic, Arab-American, and Latin American Memoirs}

In the twentieth century, diasporic memoirs flourished in Arabic and offered a long autobiographical tradition shaped by Jabra Ibrahim Jabra, Fadwa Tuqan, Mahmoud Darwish, and Mourid Barghouti. While memoirs by Barghouti, Said, and Meruane draw upon a form that has been amply reworked in Arabic and English, they are also read within the specificities of Palestinian experience in the Arab world, the United States, and Latin America. In many ways, these are transnational memoirs, drawing up geographical and cultural routes in the language in which they are produced.

Diasporic Anglophone memoirs are read within the framework of Anglo-Arab literature. In his study of the Anglo-Arab novel, Nouri Gana points out the need to elaborate what he calls "comparative, transnational, multidirectional" (10) frameworks of study of the phenomenon. He examines the transnational circuit of the Anglophone Arab novel, tracing literary affiliations and transactions. Wail Hassan reads Arab-American literature as "immigrant narratives" within a Western Orientalist tradition. While Arab-American memoirs may be considered within a tradition of Anglophone Arab writing as "a rapprochement" (al-Maleh 4) between East and West, recent memoirs such as Said's refocus attention on another East-West encounter within post-9/11ArabAmerican literature.

Anglophone Arab autobiography has witnessed a steady rise, especially in the twenty-first century, with a large portion represented by Palestinian diasporic writing. Anglophone Arab memoirs include Edward Said's Out of Place (1999); two volumes by Jean Said Makdisi, Beirut Fragments: A War Memoir (1990) and Teta, Mother, and Me: An Arab Woman's Memoir (2006). In the last quarter-century, the list of Palestinian memoirs in 
English has increased. Other Anglophone Palestinian memoirs include Ghada Karmi's In Search of Fatima: A Palestinian Story (2002) and Return: A Palestinian Memoir (2015); Raja Shehadeh's Palestinian Walks: Notes on a Vanishing Landscape (2008); Stranger in the House (2009); A Rift in Time: Travels with my Ottoman Uncle (2010); and The Third Way: A Journal of Life in the West Bank (1982); and, more recently, a collection of Anglophone Palestinian memoirs by Sharif Elmusa, Jean Said Makdisi, and Raja Shehadeh, among others (Johnson and Shehadeh).

Growing scholarship on the connections between Latin America and the Arab world offers new ways to consider narratives of return from Latin America. While Christina Civantos (2006), Ottmar Ette and Friederike Pannewick (2006), and Evelyn Alsultany and Ella Shohat (2013) have devoted attention to literary and cultural exchanges between Latin America and the Arab world, literary ties between Palestine and Latin America are largely unexamined. Cecilia Baeza (2014) focuses on the large Palestinian community in Chile and Viola Raheb and Adnan Musallam (2012) examines the history of Palestinian migration to Latin America.

Memoirs by Barghouti, Said, and Meruane traverse diasporas in the Arab world, the United States, and Latin America. Each of the encounters with Palestine is intimately intertwined with the writer's history: Barghouti returns from exile to post-Oslo Ramallah; Said looks for Palestine in the United States in the 1980s and post-9/11; and Meruane "becomes" Palestinian as an expression of her growing solidarity for Palestine in the twenty-first century.

\section{Seeing Palestine}

In I Saw Ramallah, Barghouti (b. 1944) chronicles his return to his village of Deir Ghassaneh in 1996 after a thirty-year exile. Exploring the poet's exile from Palestine after the 1967 War and his return to Ramallah in 1996, I Saw Ramallab offers a narrative of return. While I Saw Ramallah belongs to a long autobiographical tradition in Arabic with intertextual allusions to Fadwa Tuqan's Riḥlah jabaliyah, rị̣lah șa 'bah (A Mountainous Journey: An Autobiography, 1985) - Barghouti pens two memoirs set between Egypt and Palestine. Barghouti contributes to the genre in Arabic by examining the effects of dispossession between Palestine and Egypt where he settled and writes for an Arab audience familiar with the fate of Palestinians and Palestinian autobiography. Moreover, he underscores the transnationalism of the memoir in which the poet's trajectory spans Palestine, Egypt, and Europe. Born in the Palestinian village of Deir Ghassaneh in 1944, Barghouti moved to Cairo to attend university from 1963 and settled in Egypt after the 1967 War. In 1977, he was deported from Egypt, settling in exile in Budapest. Embedded in a national narrative, I Saw Ramallah is shaped by the communal story from the loss of Palestine in 1948 to the poet's return in 1996.

Barghouti animated Palestinian autobiographical production through his prose memoirs. The forms he reworks in I Saw Ramallah are multifarious: memoir, poem fragments, anecdotes, and travelogue. Set between Egypt and Palestine, I Saw Ramallah evolves from the exile and return of the poet (Abdel Nasser). The poet's movement and the memoir's migration between Cairo and Ramallah challenge the regulation of mobility in Palestine and Egypt epitomized in experiences of deportation, checkpoints, and curfews. Indeed, the memoir metaphorically challenges the firmly drawn borders 
imposed by Israel through its migration between Egypt and Palestine and illuminates the post-Oslo Palestine to which the poet returns in 1996.

Born in the Palestinian village of Deir Ghassaneh in 1944, Barghouti moved to Cairo to attend university from 1963 and settled in Egypt after the 1967 War. In 1977, he was deported from Egypt, settling in exile in Budapest until his return to Cairo in 1995. Embedded in a national narrative, I Saw Ramallah is shaped by the communal story from the loss of Palestine in 1948 to the return of the poet in 1996. In 1995, after his return to Egypt, Barghouti wrote I Saw Ramallah, a memoir that narrates his return to Palestine and underscores the centrality of his exile after the 1967 War and the Israeli occupation of the West Bank to his poetry.

I Saw Ramallah opens with the poet's return to Palestine after thirty years: "Here I am crossing the Jordan River"' (1). The poet contemplates the Jericho Bridge (formerly Allenby Bridge), a checkpoint between Jordan and the West Bank on which exiles are interrogated and which he crossed from Ramallah to Amman on his way to attend Cairo University in 1966. The narrator cites the names of the Bridge in colonial history and common language:

Fayruz [the famous Lebanese singer] calls it the Bridge of Return. The Jordanians call it the King Hussein Bridge. The Palestinian Authority calls it al-Karama [Dignity] Crossing. The common people and the bus and taxi drivers call it the Allenby Bridge. My mother, and before her my grandmother and my father and my uncle's wife, Umm Talal, call it simply: the Bridge. (Ra'aytu 15; I Saw Ramallab 10)

In 1996, the poet stands on the Jordanian bank on the lookout for the signal to cross the bridge and enter Palestine. This is a moment of return narrated through his perception of the bridge, which recalls the memory of the poet's return to Cairo in 1966 and the 1967 War that would commence his exile. He was about to graduate from Cairo University in 1967 but on the morning of June 5, 1967, he learns from Voice of the Arabs radio station that "Ramallah is no longer mine and that I will not return to it. The city has fallen" (Ra'aytu 7; I Saw Ramallah 3). Forbidden entry into Palestine, he discovers "displacement" in the summer of 1967 and the sense that Ramallah is no longer his own enforces the implication in the title: to see Ramallah is to lay claim to his city. ${ }^{2}$ In a sense, too, by seeing Ramallah again he encounters the tragedy of the occupation. Thirty years later, the poet on the West Bank of the Jordan River declares: "This then is the 'Occupied Territory'?" (Ra'aytu 10; I Saw Ramallah 6). Rather than the homeland in his poetry, the poet comes into contact with the reality of Palestine upon his return: "It is no longer 'the beloved' in the poetry of resistance [...] it is not an argument or a metaphor" (Ra'aytu 11; I Saw Ramallah 6). The poet en route to Ramallah — "I the individual, the stranger who leaned toward silence and solitude" (I Saw Ramallah 65) returns from exile, where he perfected "his solitude" (Barghouti, I Was Born There 170), to Palestine.

I Saw Ramallah narrates a return and a rediscovery of the geography of Palestine in parallel with a contemplation of the poet's status through repatriation. The poet was allowed no identity card and therefore no citizenship of the Occupied Territories; he is unable to enter Jerusalem; he returns to apply for a "reunion" identity card to grant him

1. Subsequent references are to the Arabic edition (Ra'aytu), followed by the English translation (I Saw Ramallah).

2. The word in the Arabic edition of I Saw Ramallab is ghurba (Ra'aytu 8) of which a more literal translation would be "estrangement." 
the right to citizenship after thirty years and to obtain a visa for his Cairo-born son Tamim (the Palestinian-Egyptian poet Tamīm Barghūtī) to visit Palestine. The expropriation of land and water has changed the landscape. The poet notes: "I no longer know the geography of my own land" (I Saw Ramallah 10). When he returns to his ancestral village, he observes the Israeli settlements: "The Settlements are the Palestinian Diaspora itself" (30). In Deir Ghassaneh, the poet encounters the effects of the occupation and thus sees in the settlements what impedes the sense that he has fully returned home.

I Saw Ramallah focuses on the fellowship with poets and writers in Barghouti's history. The poet-narrator preserves an iconic image of the Palestinian writer Ghassan Kanafani (Ghassān Kanafānī) in his office in Beirut and the posters of emblems of liberation movements in Asia, Africa, and Latin America plastered on the walls: "The star on Guevara's beret;" Neruda, "the words of Cabral, [...] and the vision of Fanon" (Ra'aytu 22; I Saw Ramallab 16). These observations invoke an iconography of Third World liberation movements within the Palestinian struggle. In Wulidtu hunäka, wulidtu buna (I Was Born There, I Was Born Here, 2009), his second memoir, the poet invokes Latin American poets further: 'I'd wonder at the 'blooming good health' of Pablo Neruda, because he looked like a bank director - as though a poet had to look wasted, half dead, and pale, like someone who's fallen into a chasm or just been pulled out of one!" (Wulidtu bunaka 27; I Was Born There 15). What he notes as his fellow poet's "blooming health" in fact creates a contrast with the wasted poet fated to fall into the spiral of dispossession.

Another story of exile and return is narrated in parallel in I Saw Ramallah: his return to Cairo. In 1977, he was visited by six plainclothes policemen of the State Security Service on the morning of the feast and deported. In 1995, he was permitted to return to Egypt after a seventeen-year prohibition. The history of his exile and deportation creates a narrative between "the clarity of displacement" and "the uncertainty of return" (I Saw Ramallah 73). As the history of his separation from his family, his wife Egyptian writer Radwa Ashour and his son Tamim, shows, his return to Egypt and subsequently to Palestine is fraught with uncertainty.

I Saw Ramallah explores the poet's relationship to Palestine and reworks the form to restage the drama of exile and return. Barghouti contributes to the form through his poetic memoir and the transnational focus of his memoirs, resituated between Palestine and Egypt. His memoir of return turns attention to return through the Allenby Bridge, the poet's estrangement in Ramallah, return to Deir Ghassaneh, and travel to Jerusalem from which he is barred, reworking experiences that are central to the genre in Arabic while incorporating an iconography of Third world liberation movements from the 1950s and 1960s. The memoir also shows that the productive intertwinings of Palestine and Egypt animate the poet's narrative of return.

\section{Looking for Palestine}

Another Anglophone memoir in a growing body of Arab-American memoirs is the newly published Looking for Palestine: Growing Up Confused in an Arab-American Family by American-born writer and actress Najla Said (b. 1974). While Said enters a long tradition of Anglophone memoirs on Palestine, including her father Edward Said's Out of Place, her memoir explores Palestine as part of post-9/11 Arab-American literature 
and its examination of Palestinianness in the diaspora. ${ }^{3}$ Looking for Palestine belongs to a genre of Palestinian memoirs whose concerns and commitments are interwoven with a history of colonialism and dispossession. Said examines her Palestinian and Lebanese background in the 1980s and post-9/11 America in an Arab-American memoir in English. Unlike Barghouti, Said has never lived in Palestine and is a third-generation American who was born in the US, but discovers Palestine belatedly - through her father's activism and later by accompanying him on a tour to Palestine. Looking for Palestine expresses her belated identification with Palestinians, though she does not identify with Arabs in America and the ways they were represented in the 1980s.

Said writes in the US with little direct knowledge of Palestine about a hostile Orientalizing moment in the 1980s during the Arab-Israeli conflict through to the effects of the 9/11 attacks. Looking for Palestine shows a growing identification with Palestine and a belated discovery of hyphenated Arab-American identity. The memoir does not focus on Arab immigrants to America. Rather, Said writes of growing up with little understanding of her Arabness and her discovery of her Lebanese and Palestinian heritage. In Looking for Palestine, she belongs to the generation of Arab-Americans born and raised in the US and introduces the post-9/11 Arab-American whose understanding of Arab-American culture also entails a discovery of Palestine. Set in the US, Looking for Palestine explores Arab-American subjectivity to counter prevailing stereotypes of Arabs in American culture. In the memoir, Najla tours Gaza, where she has a sense of the occupation and apprehends Palestine through her father's activism, but looks for Palestine and discovers her heritage in the US.

Born to a prominent Palestinian father, Edward Said, and a cultured Lebanese mother, Said grew up in 1980s New York at a moment of intense political instability in the Middle East and misrepresentation of the Arab-Israeli conflict in the West. Her memoir belongs to a body of work made up of the memoir of her celebrated father and a new twenty-first century generation of memoirs focusing on Arab-American and Arab subjectivity vis-à-vis Palestine. Adapted from her play Palestine, Looking for Palestine, it focuses on her confusion and self-conflict about her cultural background in 1980s and 1990s New York. Said expanded her play into a memoir to explore further her confusion, insecurities, and the complexity of a "mixed-up identity" (Looking 254). She writes: "With a great deal of outside encouragement and support, in 2009 I turned my life story into a play, and the play has now evolved into this book" (253). Responding to the profound reception of her play, she further challenges stereotypes and images of the Middle East in post-9/11 America through a story that is both specific and broad in her memoir. Her confusion, an echo of Said's being out of place in Egypt and the United States, reworks the trajectory of Out of Place through the examination of her Arab-American adolescence in New York, where her parents' identification with Palestine and Lebanon appears to be at odds with the world of her youth.

In Looking for Palestine, Said works to reconcile her Arab-American girlhood with her parents' identification with Palestine and Lebanon in a process by which she has to

3. In the last quarter-century, the list of Palestinian memoirs in English has increased. For other Arab American Anglophone memoirs, see Hassan (2011). Other Anglophone Palestinian memoirs include Ghada Karmi's In Search of Fatima: A Palestinian Story (2002) and Return: A Palestinian Memoir (2015). See also Raja Shehadeh's Palestinian Walks: Notes on a Vanishing Landscape (2008); Stranger in the House (2009); A Rift in Time: Travels with my Ottoman Uncle (2010); and The Third Way: A Journal of Life in the West Bank (1982). For new Anglophone Palestinian memoirs on exile by Sharif Elmusa, Jean Said Makdisi, Raja Shehadeh and others, see Penny Johnson and Raja Shehadeh, Seeking Palestine (2013). 
continually take the measure of her subjectivity through her father's secular humanism and her parents' Arabness as well as rising anti-Arab sentiments and the Arab-Israeli conflict. A Christian Palestinian-Lebanese-American growing up in a Jewish neighborhood on the Upper West Side in the 1970s, she is aware of the complexities of her identity in ways that echo Edward Said's self-awareness of the differences between his family and the Cairene and colonial community of 1940s Cairo in Out of Place. The memoir opens with an unequivocal statement: "I am a Palestinian-Lebanese-American Christian woman, but I grew up as a Jew in New York City. I began my life, however, as a WASP" (Looking 2). Said goes on to chronicle her White Anglo-Saxon Protestant girlhood, growing up with Jewish friends, "steeped in secular, humanist thought" (133). Throughout her youth, she learns the complexities of categorizations of culture and nationality and works through prevalent cultural stereotypes.

Set in Manhattan's Upper West Side, her home frequented by the Western world's prominent writers and figures of the Palestinian Resistance, and Chapin School on the Upper East Side of Manhattan, where she feels her otherness through her appearance, nationality, name, and the conflation of ethnicity with religion, or Arab with Muslim, Looking for Palestine focuses on her Arab-American background in the United States. She then parses the complex set of filiations in her youth - Arab and American - while being unaware of the political landscape of the Middle East prior to her visits to Palestine and Lebanon. In her youth, she enacts a separation from her Arab heritage and the representations that have characterized the Orientalism on which her father's scholarship is founded. A baptized Episcopalian, she attended Chapin, the private Upper East Side girls" school, where she grew up "absorbed in the world of Jewish culture" (Looking 126). A Chapin schoolgirl, she has "an instant awareness" of her "differences" (2) and works to understand her world, culture, and family amid perceptions of Arabness as "barbaric" and "backward" (3). She notes that her awareness of her "physical awkwardness" was at a moment of rising tensions and growing instability in the Middle East in the 1980s (82). On her return from Lebanon, in the summer of 1982, and her experience of the bombing of Beirut, she notes: "I began to realize that even if I didn't entirely identify with Arabs as they were presented to me in America, I actually was one of them just as much as I was an American from New York" (99).

The scenes in which the young Najla recalls her father's explanations of the politics of representation made famous in his 1978 Orientalism in her youth evoke shared moments and, at the same time, underscore her confusion about her Arabness and his advocacy for Palestine in the United States. The young Najla seems affected by her father's revolutionary critical practice insofar as she works to make sense of the reality of Palestinian and Lebanese affiliations in the New York of her youth. Looking for Palestine focuses on an Arab-American adolescent, confused about her father's identifications and uncertain of her Arabness, who rediscovers her roots. Though surrounded by Arabic and aware of her parents' identification with Arab culture, she is assailed by Orientalist images on TV. She writes, "While my father was writing books about this very subject, I was looking at the images of Arabs on TV and in the movies and then looking back in the mirror, confounded" (63).

Said chronicles the family's return to Palestine upon her father's diagnosis with leukemia and a visit to Gaza's Jabaliya refugee camp. An acceptance of her heritage follows her visit. In Palestine, she notes that the landscape is riddled with small Arab towns 
surrounded by settlements. She recounts her awkwardness and incongruity in Jerusalem and Gaza: "The Arabs spoke to me in Hebrew, or Italian, or Spanish, but never in Arabic, and I smiled awkwardly, unsure of how to explain myself" (160). Nonetheless, she remarks upon the centrality of Palestine after her 1992 tour: "Though I have never returned to Palestine, Palestine always returns to me" (250). Her trip thus becomes central to her growing identification with Palestinanness in the United States.

The 9/11 attacks on the World Trade Center and the ensuing American responses elicit a change that contrasts with her distance and separation from her Arab background in the 1980s. She recalls feeling the moment when people in the vicinity came to the "collective, silent conclusion" that the perpetrators were Palestinians and notes: "that was the moment my life changed forever" (214; emphasis in original). In post-9/11 America, she becomes an Arab-American, a term about which she expresses ambivalence: 'I don't feel entirely American, never have, but it's not because I don't want to or because I don't seem it - I do want to, I do seem it. I don't feel entirely Arab though either, for the same reasons. But I also certainly don't feel like any combination of the two" (217; emphasis in original). She joins a group of theater artists of Arab origin to work on a documentary theater project and her work with the group expresses her self-understanding in the aftermath of the 9/11 attacks: "in America, there is no doubt that since 9/11, I am officially an Arab, bridging the gap between two worlds that don't understand each other" (251). While she writes that she is neither fully American nor fully Arab in the US, she notes the categorizations to which she has been subjected in post-9/11 America, writing in the US in English to work through the nuances of her Arab-Americanness in the twenty-first century.

Looking for Palestine contemplates the experience of growing up in an immigrant family in the United States and the journey toward the understanding of a new hyphenated Arab-American identity in a world that changes from rampant misrepresentations of Arabness during the Palestinian struggle and the Lebanese civil war (1975-1990) to the post-9/11 climate of burgeoning anti-Arab sentiments. When she runs into a protest of young women wearing "Free Palestine" T-shirts while walking up Broadway, she is beset by the intense feeling she experiences when the word "Palestine" is spoken aloud and feels "immensely grateful" that they are protesting for her and for Palestinians and wants to join them and "be a revolutionary" (252). In a climactic moment, she notes her intense identification "because I am this girl, this young woman [...] this [...] me, I am this Palestinian" (252; emphasis in original). Though she creates theater as an ArabAmerican and becomes more certain of her Palestinian identity, the Upper West Side remains her home. She asserts, "None of it changes the fact that I started and finished school in America, that English is my first language, that I still live in New York" (253). Though she asserts that English is her first language and she lives in New York, Said is emblematic of Palestinians in the diaspora - American and Latin American - who look for Palestine and discover an Arab heritage. By the end of the memoir, she has become Arab-American in concert with that particular post-9/11 historical moment and, though she has found solidarity with an Arab-American theater group, she directs her creative energies to a solo show devoted to Palestine. For Said, being Palestinian is thus not only an affirmation of her heritage but also an expression of solidarity. 


\section{Becoming Palestine}

Volverse Palestina can be read within a history of Arab migration from the Ottoman Empire to the New World and the presence of a large Palestinian community in Chile with historical ties to Palestine since the nineteenth century. Moreover, Meruane's memoir has appeared at a moment of pro-Palestine solidarity in Latin America. Over the past decades, understanding of and support for Palestine have grown in Latin America in spite of the fact that Palestinians who migrated to Latin America since the late nineteenth century held Turkish passports and were known as "Turks" (Abugattas 118). Until recently, the question of Palestine in Latin America was debated against a history of adoption of the European or North American line and Latin American Orientalism (Abugattas 120). Unlike Arab-Americans, Palestinian immigrants assimilated into Latin American culture. Currently, Chile has "the most active group" of Latin Americans of Palestinian descent dedicated to the Palestinian struggle and has seen the growth of a "pro-Palestinian movement" in the twenty-first century (Baeza, "Palestinians in Latin America" 67). Baeza notes: "Today, Palestinians in Latin America are a highly active minority, both culturally and politically" ("Palestinians in Latin America" 68). Awareness of and solidarity for Palestine have grown among Palestinians in Latin America, especially Chile, and, as Baeza notes, writers "of Palestinian ancestry express their solidarity with Palestine in their work and through their activism" "Palestinians in Latin America" 69). Meruane writes within that revival of interest in Palestine and understanding of the Palestinian struggle, and return to ancestral ties.

Latin American writers of Arab ancestry have traced these cultural ties in recent narratives of return, notably Miguel Littín's Crónicas Palestinas (2001) and Lina Meruane's Volverse Palestina. Lina Meruane (b. 1970), a Chilean writer of Palestinian ancestry, is one of the foremost contemporary writers in Chile. Volverse Palestina focuses on her trip to Palestine in March 2012 to trace the origins of her family name. Unlike Barghouti and Said's memoirs, Meruane's memoir offers an exploration of her origins and an understanding of Palestine within growing Latin American solidarity. While Barghouti returns to his birthplace and Said undertakes a trip with her father, Meruane crosses into Palestine, writing a Latin American chronicle of return. Writing in Spanish between New York and Chile, Meruane explores the understanding of Palestine and her own excavation of her Palestinian heritage in Latin America.

Volverse Palestina chronicles Meruane's trip to Palestine in March 2012. Uniquely, Meruane examines Palestine through her family's history in Latin America and her trip. In Volverse Palestine, Palestine assumes importance as her own narrative of return in the place of her father and becomes a form of political activism. Unlike her father who would not return after the dispossession, Meruane undertakes a trip to Palestine. The memoir focuses on Meruane's discovery of her ancestry in Chile, the history of her grandfather and father's migration to Latin America, and her own trip to Palestine.

Volverse Palestina, written in the form of her 2012 autobiographical novel Sangre en el Ojo (Seeing Red), set in New York where a young Chilean writer moves for doctoral study and suffers blindness after a stroke, is a memoir and a travelogue. Unlike the genre of testimonio produced in response to the violence of Latin American dictatorships in the 1970s and 1980s, Meruane's memoir appeared at a moment when personal and political memoirs flourished in Latin America (Meruane, "Lina Meruane: el reencuentro con la historia"). 
For Meruane, the trip is a point of entry to Palestine that captures the minute details of everyday life. Her chronicle recounts the harassment endured by travelers of Palestinian descent to the Occupied Territories, interrogations by Israeli officers at ports of entry, a heavy military presence, and the systematic use of violence. As a Chilean with a Palestinian surname, she has no freedom of movement, goes through security, has to pass through army checkpoints, and joins "political tours" ("recorridos políticos") that help her gain entry into Hebron or a small town in Bethlehem.

In Volverse Palestina, Meruane offers an explanation of her "return" in her Chilean reworking of the genre:

Return. I am assaulted by that verb whenever I think about the possibility of Palestine. I tell myself: it wouldn't really be a return, just a visit to a land I've never been to before, a land of which I have no images of my own. Palestine has always been a murmur in the background, a story I tell myself to rescue a shared origin from extinction. The return would not be my own, I repeat. It would be borrowed from someone else, made in someone else's place. My grandfather's, perhaps. Or my father's. But my father has had no desire to set foot in the occupied territories. He has only been as far as the border. Once, from Cairo, he turned his already elderly eyes eastward and let them rest there for a moment towards Palestine. ${ }^{4}(11)$

Unlike Barghouti who crosses the bridge, a symbol of return, and Said who returns with her father, Meruane presents her father's near-return; he never crossed the border into the West Bank because he refused to pass through the checkpoints. On another occasion, her father stands at the Jordanian border but is unable to approach the border crossing. Her mother insists on crossing into the West Bank because she had come to feel part of the extended clan. Her father marches in the opposite direction, refusing to subject himself to interrogation at the Israeli border; to be called a stranger in his own land, where his father's house still stands and of which he has been "disinherited"; and he dreads the prospect of approaching a house, now full of strangers, without a key and knocking on the door. The scene her father conjures up is of settlements, security cameras, soldiers, barbed wire, and rubble. Like countless Palestinians who could no longer return after the Nakba (catastrophe) and the founding of Israel in 1948, the 1967 War, and the annexation of Palestinian territories, her grandfather and father would assimilate into Chilean culture. For her, she completes her father's return to Palestine, tracing the Palestine-Chile journey undertaken by her grandfather and father through the Santiago-Jaffa route. In New York, she muses: "I think that Chile is my own Levant. There is no longer any family in Beit Jala but a couple of women who carry the name Meruane" (30). ${ }^{5}$

4. Volverse Palestina has appeared in two editions: Volverse Palestina (2013), published by Literal and Conaculta in the U.S. and Mexico; and Volverse Palestina (2014), an expanded edition published by Penguin Random House in Chile and Spain. Subsequent references are to the first Literal edition. Unless otherwise noted, all translations are my own. For a translation of an excerpt from Volverse Palestina, see Rosenberg (2016). Here I quote from Rosenberg's translation of the passage: "Regresar. Ese es el verbo que me asalta cada vez que pienso en las posibilidad de Palestina. Me digo: no sería un volver sino apenas un visitar una tierra en la que nunca estuve, de la que no tengo ni una sola imagen propia. Lo palestino ha sido siempre para mí un rumor de fondo, un relato al que se acude para salvar un origen compartido de la extinción. No sería un regreso mío, repito. Sería un regreso prestado, en el lugar de otro. Di mi abuelo, acaso. De mi padre. Pero mi padre no ha querido poner pie en esas tierras ocupadas. Una vez estuvo en Egyipto. Desde El Cairo dirigió sus ojos ya viejos hacia el este y los sostuvo un momento en el punto lejano donde podría ubicarse Palestina."

5. "pensando que Chile es mi único Levante. De me familia en Beit Jala no quedan más que un par de mujeres que llevan en algún lugar el Meruane." 
In Jaffa, Meruane encounters the reality of Palestinians under occupation and tours the city with her hosts, Ankar, her Jewish friend and his Muslim wife, Zima. En route to Jerusalem, a city surrounded by a wall of barbed wire that divides Israelis and $\mathrm{Pa}$ lestinians as well as Palestinians in the same neighborhood, she notes the site of the demolition of four hundred Palestinian villages. In the final section of the memoir, Meruane chronicles her encounter with Palestine as a return. Upon landing in Tel Aviv, she is subjected to an interrogation and her observations create central parallels between the Israeli authorities and the Pinochet dictatorship. Her interrogation focuses on the Israeli harassment of Chileans of Palestinian descent and her own growing sense of Palestinianness (la palestinidad).

Part of her experience of the reality of Palestine includes her discovery of a dizzying array of numbers: Palestinians of 1948, Palestinian refugees, and the Palestinians of 1967 who remained in the area annexed by Israel in the 1967 War. When Meruane wants to know how her grandparents would be categorized, Zima observes that what matters is the possibility of return. In that moment, Zima tucks a loose lock of hair behind her ear and Meruane does the same, mirroring her gesture. That scene underscores her special affinity with Zima and her sense that Zima's life could have been her own.

When Meruane wants to enter the Gaza Strip, a large prison, surrounded by concrete walls, and the poorest, most populated territory in the world, her friends, activists, and UNICEF representatives say, "Forget it." Because Gaza is blockaded, she goes on to Hebron. On the way, she notes the concrete wall that separates Israel from the territories, Palestinian-Muslim refugee camps, the large Kiryat Arba settlement at the entrance to Hebron, a motorway for Israelis and bullet-proof buses in which settlers travel. They encounter Israeli soldiers, a group of Arab children, and a young American guide. While they run through Hebron in the West Bank, Israel bombs the Gaza Strip. In interviews, Meruane notes that her chronicle not only traces the origins of her last name but also makes sense of a current crisis ("Lina Meruane: el activism de la letra" 15). She discovers that Palestinians must cover great distances because the roads are blocked and settlers have taken over the market. A poster on a radical settler's car reads: "I killed an Arab, and you?" (63). In Hebron, graffiti painted by settlers, mostly in English, abounds on the walls of houses and Meruane translates, puzzled: "Arabs to the gas chambers" (63).

Volverse Palestina circles back to Meruane's return in the section "Becoming Palestine." In Jaffa, on the eve of her departure to New York, Meruane contemplates the implications of her return to Palestine. As she initially set out for Palestine, she thought: "Volverme Palestina. Volver" (33) (Return to Palestine. Become it). The play on "volver" (returning and becoming) and "Palestina" (Palestine and Palestinian) in Spanish is telling: her return becomes a change that ensues from her discovery of her roots and her solidarity.

\section{Conclusion}

Each of these narratives of return contributes to global Palestinian cultural production and comparative frameworks with transnational Arabic literature, Arab-American literature focused on Palestine, and Latin American cultural production that examines Palestine through historical and cultural ties between Latin America and the Arab world. Barghouti, Said, and Meruane open up the study of networks between Arab, Arab- 
American, and Latin American literatures with a focus on Palestine. In Barghouti's memoir, Palestine is the site of return in counterpoint to Egypt. While Said's memoir is steeped in the Arab-American diaspora and her belated discovery of Palestine, Meruane's memoir is a return to her roots and an expression of solidarity. Reworking the narrative of return, these writers contribute to a polylingual literature on Palestine that lends different transnational networks to the genre. The translation and circulation of these narratives of return - Meruane's Spanish memoir - will no doubt contribute further to global Palestinian cultural production and transnational networks between Palestine and Latin America.

Tahia Abdel Nasser

American University in Cairo (Egypt)

\section{Works Cited}

Abdel Nasser, Tahia. "Between Exile and Elegy, Palestine and Egypt: Mourid Barghouti's Poetry and Memoirs." Journal of Arabic Literature 45 (2014): 244-64.

Abugattas, Juan. "The Perception of the Palestinian Question in Latin America." Journal of Palestine Studies 11.3 (Spring 1982): 117-28.

Al-Malen, Layla. Arab Voices in Diaspora: Critical Perspectives on Anglophone Arab Literature. New York: Rodopi, 2009.

Alsultany, Evelyn and Ella Shohat, eds. Between the Middle East and the Americas: The Cultural Politics of Diaspora. Ann Arbor: U of Michigan P, 2013.

BAEZA, Cecilia. "Palestinians in Latin America: Between Assimilation and Long-Distance Nationalism." Journal of Palestine Studies 43.2 (Winter 2014): 59-72.

—. "Solidaridad con Gaza." Middle East Research and Information Project. 22 July 2014. 7 December 2015 $<$ http://www.merip.org/solidaridad-con-gaza $>$.

-. "Women in Arab-Palestinian Associations in Chile: Long Distance Nationalism and Gender Mixing." Al-Raida 133-134 (2011): 18-32.

Barghouti, Mourid. I Was Born There, I Was Born Here. Trans. Humphrey Davies. Cairo: The American U in Cairo P, 2011.

—. Wulidtu bunaka, wulidtu buna. Beirut: Riad El-Rayyes, 2009.

—. Ra'aytu Rāmallāh. Cairo: Dār al-Hilāl, 1997.

-. I Saw Ramallah. Trans. Ahdaf Soueif. Cairo: The American U in Cairo P, 1997.

Bernard, Anna. Rhetorics of Belonging: Nation, Narration, and Israel/ Palestine. Liverpool: Liverpool UP, 2013.

. "Who Would Dare to Make It into an Abstraction': Mourid Barghouti's I Saw

Ramallah." Textual Practice 21.4 (2007): 665-686.

Civantos, Christina. Between Argentines and Arabs: Argentine Orientalism, Arab Immigrants, and the Writing of Identity. New York: State U of New York P, 2006.

Crónicas palestinas. Dir. Miguel Littín. Italo Retamal (Chile), 2001. 50 min.

DARivish, Mahmoud. A River Dies of Thirst. Trans. Catherine Cobham. New York: Archipelago, 2009.

ElmusA, Sharif S. "Portable Absence: My Camp Re-membered." Seeking Palestine: New Palestinian Writing on Exile and Home. Ed. Penny Johnson and Raja Shehadeh. Northampton, MA: Olive Branch P, 2013. 22-41.

Етте, Ottmar, and Friederike Pannewick, eds. ArabAmericas: Literary Entanglements of the American Hemisphere and the Arab World. Madrid: Iberoamericana, 2006.

GanA, Nouri. The Edinburgh Companion to the Arab Novel in English: The Politics of Anglo Arab and Arab American Literature and Culture. Edinburgh: Edinburgh UP, 2015.

HASSAN, Wail S. Immigrant Narratives: Orientalism and Cultural Translation in Arab American and Arab British Literature. New York: Oxford UP, 2011.

Karmi, Ghada. Return: A Palestinian Memoir. London: Verso, 2015.

-. In Search of Fatima: A Palestinian Story. London: Verso, 2009.

Makdisi, Jean Said. Teta, Mother, and Me: An Arab Woman's Memoir. London: Saqi, 2005.

—. Beirut Fragments: A War Memoir. New York: Pesea, 1990.

Mattar, Karim. "Mourid Barghouti's 'Multiple Displacements': Exile and the National Checkpoint in Palestinian Literature." Journal of Postcolonial Writing 50 (2014): 103-15. 
Meruane, Lina. Becoming Palestine (excerpt). Trans. Andrea Rosenberg. Drunken Boat 2016. 2 July 2016 <http://www.drunkenboat.com/db23/translation/andrea-rosenberg-translating-lina-meruane $>$.

—. "La Identidad no es algo fijo y esto es bueno: Lina Meruane." El Sol de México 2 October 2014.7 December 2015 < http://www.oem.com.mx/elsoldemexico/notas/n3557615.htm>.

—. "Lina Meruane: el reencuentro con la historia." Interview by Sergio Tellez-Pon. Tierra Adentro. 2 December 2014. 17 January 2016 <http://www.tierraadentro.conaculta.gob.mx/entrevistas/linameruane-el-reencuentro-con-la-historia $/>$.

—. "Lina Meruane: el activism de la letra." Interview by Roberto Careaga C. Entrevista El Mercurio. 26 October 2014: 15.

—. "Lina Meruane y su 'Volverse Palestina'.” Interview by Juan Carlos Ramirez F. Diario la Segunda. 26 November 2013: 30.

-. Sangre en el ojo. Santiago: Eterna Cadencia Editora, 2012.

-. Volverse Palestina. México: Literal Publishing, 2013.

—. Volverse Palestina. Barcelona: Penguin, 2014.

Musallam, Adnan A. "The Formative Stages of Palestinian Arab Immigration to Latin America and Immigrants' Quest for Return and for Palestinian Citizenship in the Early 1920s." Latin Americans with Palestinian Roots. Ed. Viola Raheb. Bethlehem: Diyar, 2012. 15-24.

Raheb, Viola, ed. Latin Americans with Palestinian Roots. Bethlehem: Diyar, 2012. 9-14.

SAID, Edward. Out of Place: A Memoir. New York: Alfred A. Knopf, 1999.

SaID, Najla. Looking for Palestine: Growing Up Confused in an Arab-American Family. New York: Penguin, 2013.

Salt of this Sea. Dir. Annemarie Jacir. JBA Production, 2008. $109 \mathrm{~min}$.

SheHadeh, Raja. Palestinian Walks: Forays into a Vanishing Landscape. New York: Simon \& Schuster, 2007.

-. When the Birds Stopped Singing: Life in Ramallah Under Siege. New Hampshire: Steerforth P, 2003.

-. Strangers in the House: Coming of Age in Occupied Palestine. New York: Penguin, 2002.

TūQĀn, Fadwa. Rị̉lah jabalìyah, riḥlah sa'bah. 'Ammān: Dār al-Shurūq, 1985.

-. A Mountainous Journey: An Autobiography. Trans. Olive Kenny and Naomi Shihab Nye. St. Paul, MN: Graywolf P, 1990. 